\title{
Control spectra for Quito
}

\author{
Roberto Aguiar $^{1,2}$, Alicia Rivas-Medina ${ }^{1,3}$, Pablo Caiza ${ }^{1}$, and Diego Quizanga ${ }^{4}$ \\ ${ }^{1}$ Departamento de Ciencias de la Tierra y la Construcción, Universidad de Fuerzas Amadas ESPE, Quito, Ecuador \\ ${ }^{2}$ Universidad Laica Eloy Alfaro de Manabí, Manabí, Ecuador \\ ${ }^{3}$ Departamento de Cs. Geodésicas y Geomática, Universidad de Concepción - Campus Los Ángeles, Los Ángeles, Chile \\ ${ }^{4}$ Departamento de Ingeniería Civil, Escuela Politécnica Nacional, Quito, Ecuador
}

Correspondence to: Roberto Aguiar (rraguiar@espe.edu.ec)

Received: 28 January 2016 - Discussion started: 3 June 2016

Revised: 6 January 2017 - Accepted: 26 January 2017 - Published: 13 March 2017

\begin{abstract}
The Metropolitan District of Quito is located on or very close to segments of reverse blind faults, Puengasí, Ilumbisí-La Bota, Carcelen-El Inca, Bellavista-Catequilla and Tangahuilla, making it one of the most seismically dangerous cities in the world. The city is divided into five areas: south, south-central, central, north-central and north. For each of the urban areas, elastic response spectra are presented in this paper, which are determined by utilizing some of the new models of the Pacific Earthquake Engineering Research Center (PEER) NGA-West2 program. These spectra are calculated considering the maximum magnitude that could be generated by the rupture of each fault segment, and taking into account the soil type that exists at different points of the city according to the Norma Ecuatoriana de la Construcción (2015). Subsequently, the recurrence period of earthquakes of high magnitude in each fault segment is determined from the physical parameters of the fault segments (size of the fault plane and slip rate) and the pattern of recurrence of type Gutenberg-Richter earthquakes with double truncation magnitude $\left(M_{\min }\right.$ and $\left.M_{\max }\right)$ is used.
\end{abstract}

\section{Introduction}

Ecuador is located in one of the most seismically dangerous areas of the world, a zone where the Nazca plate subducts under the American plate at a relative speed of $58 \pm 2 \mathrm{~mm} \mathrm{yr}^{-1}$ (Trenkamp et al., 2002). As a result, this tectonic movement has generated the megafault that begins in the Gulf of Guayaquil and ends in the Bocono fault in Venezuela, as shown in Fig. 1.
The megafault towards the northeast is transcurrent dextral and towards the north it is a reverse fault, with an average slip rate of $3.0-4.5 \mathrm{~mm} \mathrm{yr}^{-1}$. The fault system has a turnover rate of $2.0-4.0 \mathrm{~mm} \mathrm{yr}^{-1}$; this movement is not uniform along the fault (Winter et al., 1993; Trenkamp et al., 2002).

Concern about the seismic hazard of Quito dates back to 1587 , when an earthquake of magnitude 6.4 (magnitude estimated in Beauval et al., 2010), associated with the system of blind faults, affected the young city established in 1534 . Since then, there has not been an earthquake with a magnitude larger than 6.0, which means that there is a significant accumulation of seismic energy that will eventually be released. Therefore, the city must await new strong earthquakes.

In earthquake engineering, earthquakes are expressed by elastic design spectra. It is also well known that local soil conditions are a key factor affecting the spectrum form (Crouse and McGuire, 1996; Field and the SCEC Phase III Working Group, 2000). A recent case is the earthquake at Christchurch, New Zealand in 2011, which had a magnitude of 6.2 and a focal depth of $5 \mathrm{~km}$, generated different spectra in the commercial area of the city depending on the soil type, which affected it severely (Elwood, 2013).

In this paper, elastic response spectra, obtained deterministically for $5 \%$ damping, are presented for each of the five areas of Quito (south-central, central, north and north-central), and the soil type is taken into account. These spectra are associated with the occurrence of an earthquake of maximum expected magnitude in the fault segments Puengasí, IlumbisíLa Bota, Carcelen-El Inca, Bellavista-Catequilla and Tangahuilla. 


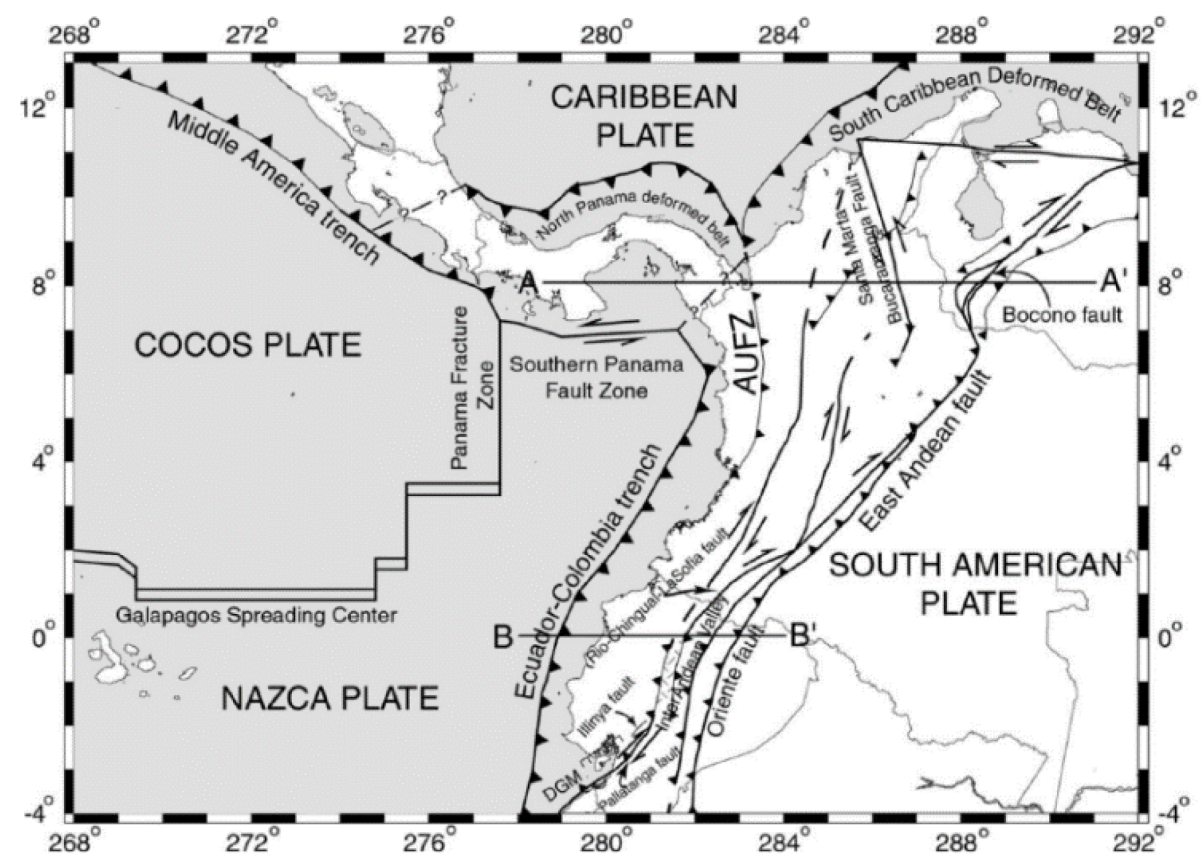

Figure 1. Plate tectonics in the northwest of South America (Trenkamp et al., 2002).

In this study we want to include the effect of proximity to the fault using ground motion prediction equations with this effect; therefore we used equations developed by Campbell and Bozorgnia (2013) (CB13), Abrahamson et al. (2013) (ASK13) and Chiou and Youngs (2013) (CY13).

The spectra results for 50 and $84 \%$ confidence levels are presented and compared to the spectrum reported by the Norma Ecuatoriana de la Construcción (2015) (NEC-15). These spectra are called control spectra since they are used to verify the performance of existing structures or those being designed using the NEC-15 code.

Comparisons between control spectra or specific response spectra obtained with empirical GMPEs (ground motion prediction equations) and a seismic code spectrum have been made in other cities or seismic zones as mentioned in GasparEscribano et al. (2008), Hao and Gaull (2009) and Nunziata et al. (2011), inter alia. Control spectra or specific response spectra are also used to estimate the seismic hazard and risk in cities or specific sites (Rivas-Medina et al., 2011, 2014a).

\section{Blind faults in Quito}

Quito is a south to north elongated city which borders west with the Western Cordillera mountains (WC) as shown in Fig. 2. The east is limited by several hills which are Puengasí (P), Ilumbisí-La Bota (ILB), towards north the Inca Calderon hill (CEI), and at the north the BellavistaCatequilla (BC), where the last moderately strong earthquake of 12 August 2014 originated, which had a magnitude of 5.1 and focal depth of $5 \mathrm{~km}$ (Aguiar et al., 2014). The Guayl-

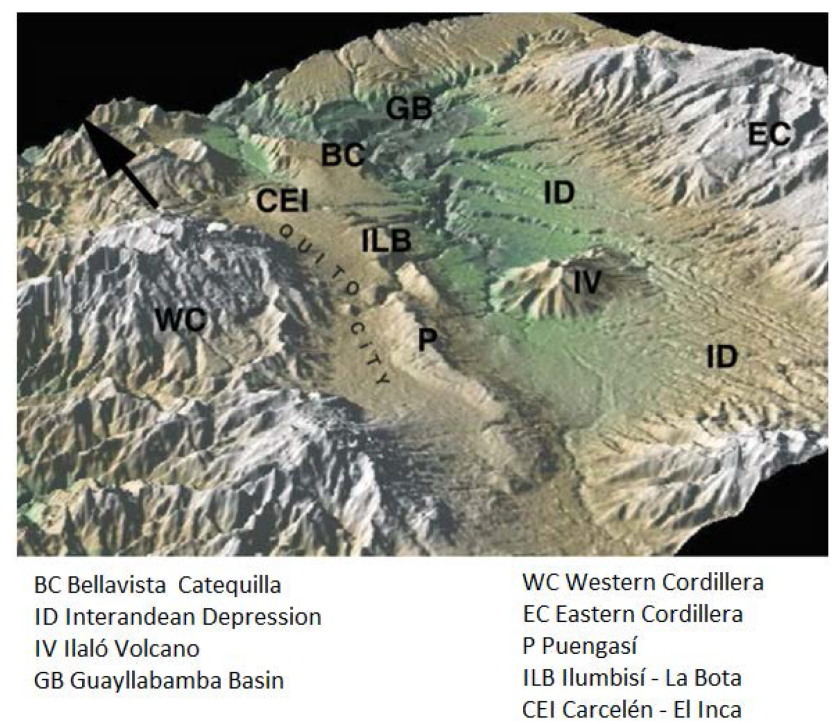

Figure 2. 3-D view of the Andean valleys (Alvarado et al., 2014).

labamba basin, GB, can also be observed. On the right of Fig. 2, the inter-depression ID is observed too. It is formed by the Chillos Valley to the north and Tumbaco Valley to the south. They are separated by the Ilalo volcano IV.

Quito is $2800 \mathrm{~m}$ a.s.l. (meters above sea level) and the valleys are $2400 \mathrm{~m}$. The hills P, ILB, CEI, and BC have heights that vary between 100 and $300 \mathrm{~m}$. They are the external signs of the existence of blind reverse faults that raise from 2 to $4 \mathrm{~mm} \mathrm{yr}^{-1}$ (Alvarado et al., 2014) and are shown in Fig. 3. It 


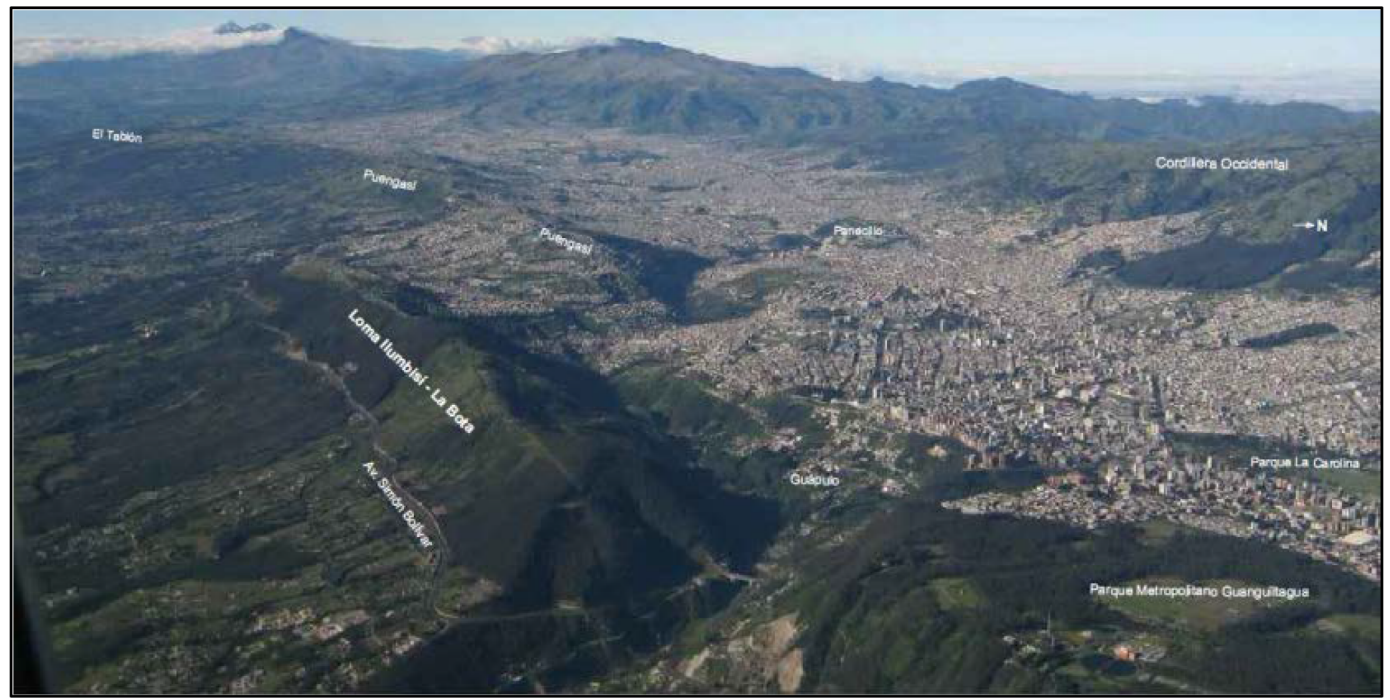

Figure 3. The Ilumbisi-La Bota hill at the front, and the Puengasí hill at the rear.

can be observed that in some areas houses have been built on both sides of the hills (Puengasí).

Note in Fig. 3 that the top of Puengasí and Ilumbisí-La Bota hills, which shows the existence of inverse faults behind them, do not form a single continuous line, demonstrating the probable existence of a strike-slip fault between them. All this makes clear that the city stands on a complex fault system.

In Fig. 3, to the left side of the Ilumbisí-La Bota hills, the Simon Bolivar Avenue can be seen, as well as the start of the Tumbaco Valley and further south the Chillos Valley. On the bottom right side of this figure, at the slopes of the hills, the Guápulo shrine is located, and towards the north is the Metropolitan Park, where a seismic refraction study was conducted to determine the velocity of shear wave $V_{\mathrm{s} 30}$ on a rocky outcrop (Castillo, 2014).

Table 1 shows the segments of the thrust faults that cross the city of Quito; the length of the rupture surface was estimated by Alvarado et al. (2014) and the area of rupture and the expected maximum magnitude were estimated using the equations proposal in Leonard (2010). The average dip angle of the thrust faults is 550 westward (Alvarado et al., 2014). Even though a fault could be considered well known, there is always uncertainty in the determination of the parameters defining the geometry of it, which is why strongmotion models should be used to somehow minimize this uncertainty. For example, in the model of CY13 the $Z_{\mathrm{TOR}}$ variable is the depth to the upper edge of the fault (in kilometers) and it is worked statistically using the variable $\Delta Z_{\mathrm{TOR}}$. Indeed, $\Delta Z_{\mathrm{TOR}}$ is defined as the difference between the observed value $Z_{\mathrm{TOR}}$ and the expected value $E\left[Z_{\mathrm{TOR}}\right]$.
Table 1. Area and length of rupture of the fault segments and maximum expected magnitude (Alvarado et al., 2014).

\begin{tabular}{lrrc}
\hline Segment & $\begin{array}{r}\text { Area of } \\
\text { rupture } \\
\left(\mathrm{km}^{2}\right)\end{array}$ & $\begin{array}{r}\text { Length of } \\
\text { rupture } \\
(\mathrm{km})\end{array}$ & $\begin{array}{r}\text { Magnitude } \\
\left(M_{\mathrm{W}}\right)\end{array}$ \\
\hline Puengasí & 259 & 22 & 6.4 \\
ILB & 176 & 15 & 6.2 \\
CEI & 82 & 7 & 5.9 \\
BC & 191 & 17.5 & 6.3 \\
Tangahuilla & 108 & 12 & 6.0 \\
\hline
\end{tabular}

where $Z_{\text {TOR }}$ is the observed depth to the upper edge of a given fault, and $E\left[Z_{\mathrm{TOR}}\right]$ is the value obtained with Eq. (2) that has been inferred for reverse and oblique reverse faults.

$E\left[Z_{\mathrm{TOR}}\right]=\max [2.704-1.226 \max (M-5.849,0), 0]^{2}$,

where $M$ is the expected magnitude in the geological fault.

The CB13, ASK13 and CY13 prediction equations will control the level of confidence with the addition of the $\varepsilon$ and $\sigma$ variables, where $\sigma$ is the standard deviation and $\varepsilon$ is a number of standard deviation, if $\varepsilon=0$, for a confidence level of $50 \%$ (average), $\varepsilon=1$ for a confidence level of $84 \%$, and $\varepsilon=2$ for a confidence level of $95 \%$. Obviously, the higher the value of $\varepsilon$, the higher the confidence level and the greater the spectral ordinates. The level of confidence in the determination of the spectral coordinates could induce higher construction costs. Therefore, seismic regulations allow a probability of exceedance of ground motion as a function of the use of the structure.
$\Delta Z_{\mathrm{TOR}}=Z_{\mathrm{TOR}}-E\left[Z_{\mathrm{TOR}}\right]$, 
Table 2. Parameters considered by the selected strong movement models.

\begin{tabular}{llll}
\hline Model & $\mathrm{ASK} 13$ & $\mathrm{CB} 13$ & $\mathrm{CY} 13$ \\
\hline Source parameter & & & \\
\hline Magnitude & $\mathrm{X}$ & $\mathrm{X}$ & $\mathrm{X}$ \\
Mechanisms & $\mathrm{X}$ & $\mathrm{X}$ & $\mathrm{X}$ \\
Dip & $\mathrm{X}(\mathrm{HW})$ & $\mathrm{X}$ & $\mathrm{X}$ \\
Rupture width $(W)$ & $\mathrm{X}$ & $\mathrm{X}$ & $\mathrm{X}$ \\
Hanging-wall effect $(\mathrm{HW})$ & $\mathrm{X}$ & $\mathrm{X}$ & $\mathrm{X}$ \\
Depth of the rupture surface $\left(Z_{\mathrm{TOR}}\right)$ & $\mathrm{X}$ & $\mathrm{X}(\mathrm{HW})$ & $\mathrm{X}$ \\
Depth of the hypocenter $\left(Z_{\mathrm{hyp}}\right)$ & & $\mathrm{X}$ & \\
\hline Types of distances & & & \\
\hline$R_{X}$ distance & $\mathrm{X}(\mathrm{HW})$ & $\mathrm{X}(\mathrm{HW})$ & $\mathrm{X}(\mathrm{HW})$ \\
Joyner-Boore distance $\left(R_{\mathrm{jb}}\right)$ & $\mathrm{X}(\mathrm{HW})$ & $\mathrm{X}(\mathrm{HW})$ & $\mathrm{X}$ \\
Rupture surface distance $\left(R_{\mathrm{rup}}\right)$ & $\mathrm{X}$ & $\mathrm{X}$ & $\mathrm{X}(\mathrm{HW})$ \\
$R_{Y}$ distance & & \\
$R_{Y_{0}}$ distance & $\mathrm{X}(\mathrm{HW})$ & & \\
\hline Site effects & & & \\
\hline$V_{\mathrm{s} 30}$ & $\mathrm{X}$ & $\mathrm{X}$ & $\mathrm{X}$ \\
$Z_{1.0}$ & $\mathrm{X}$ & $\mathrm{X}$ & \\
$Z_{2.5}$ & & & \\
\hline Other effects & & $\mathrm{X}$ \\
\hline Directivity & & $\mathrm{X}$ \\
Attenuation & & \\
\hline & & & \\
\hline
\end{tabular}

\section{Strong movement models}

The CB13, ASK13 and CY13 prediction equations (Campbell and Bozorgnia, 2013; Abrahamson et al., 2013 and Chiou and Youngs, 2013, respectively) are considered, so that $5 \%$ damping elastic response spectra for surface type geological faults can be obtained. The database of the first three models is the PEER NGA-West2, which contains over 21000 accelerograms for the three components of ground motion of earthquakes recorded in different parts of the world, with magnitudes ranging between 3.0 and 7.9. From this record wealth, CB13 employed 15521 records from 322 earthquakes, while ASK13 employed with 15749 records of 326 earthquakes. Finally, the model of CY13 employed with 12444 records of 300 earthquakes. From this grand total, 2587 records were selected from 18 non-California earthquakes.

All three models have very important databases that accredited their equations of ground motion. Table 2 shows the variables that each of the models considers. It shows that there is little difference between them, in general, so that the spectral shapes tend to be similar.

The CY13 model considers the effect of directivity, which is very important when the site of interest is very close to the fault, unlike the other two models that do not consider it. Its formulation is based on studies by Spudich and Chiou (2008) and developed by Spudich (2013). In the first study, the IDP directivity factor (isochrone directivity predictor) is consid-

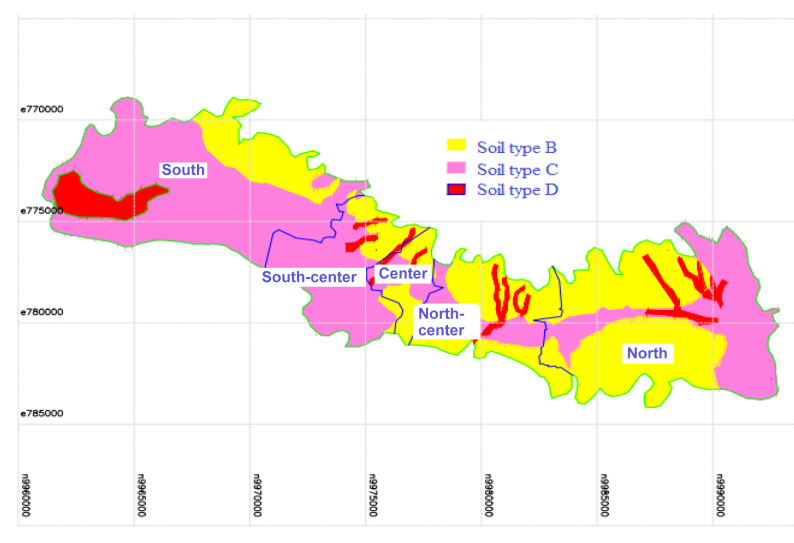

Figure 4. Soil classification in Quito.

ered. Instead, in the second, the direct point parameter (DPP) model is used, but the variables are expressed incrementally, for example $\Delta_{\mathrm{DPP}}$ and $\Delta Z_{\mathrm{TOR}}$, which are also calculated incrementally in the CY13 model.

In addition, the CB13 considers the depth of the hypocenter (ZHYP) as a parameter in determining the spectral acceleration, which is ignored in the other models. To check any difference, it is important to consider some strong movement models for the determination of the spectra (for case studies) or ground motion attenuation equations (for seismic hazard studies).

\section{Soil classification in Quito}

It is important to emphasize that the spectra shape changes according to the type of soil, as can be observed later in Fig. 6. Therefore, a brief explanation of the type of soils in Quito is presented in the following paragraphs. In Fig. 4, the five zones of the Metropolitan District of Quito are presented: south, south-central, central, north-central and north. For each zone it is necessary to determine the response spectra associated with blind reverse fault segments. For example, the Puengasí fault starts in the south and reaches the center of the city. Its rupture length, associated with a earthquake of magnitude 6.4, is $22 \mathrm{~km}$ (Table 1), so this fault is the source of the highest spectral accelerations in the following areas: north-central, central, south-central and south.

At the north of the city, the fault segment associated with the highest spectral accelerations is Ilumbisí-La Bota (ILB), where an earthquake of 6.2 maximum magnitude is expected (Alvarado et al., 2014). The other faults that exist in the north do not generate spectra with larger ordinates due to being furthest from the city.

There have been several studies to classify soils in Quito, the first of them presented by the Politécnica Nacional in 1994 from a geological point of view and the second study was presented by Valverde et al. (2002), who classified soils according to the Ecuadorian code of year 2000 (CEC, 2000). 
They identified three types of soils called S1, S2 and S3 (Aguiar, 2003): (1) in the soil profile S1, the speed of the shear wave is $V_{\mathrm{s} 30} \geq 750 \mathrm{~m} \mathrm{~s}^{-1}$, and the periods of soil vibration are less than $0.2 \mathrm{~s}$; (2) in the soil profile $\mathrm{S} 2$, the periods of soil vibration are between 0.2 and $0.6 \mathrm{~s}$ and (3) in the soil profile $\mathrm{S} 3$ the periods are greater than $0.6 \mathrm{~s}$.

In the NEC-15 norm, there are six types of soil: (1) the soil profile A corresponds to competent rock with $V_{\mathrm{s} 30}>1500 \mathrm{~m} \mathrm{~s}^{-1}$; (2) the soil profile B corresponds to a mean stiffness rock with $760 \mathrm{~m} \mathrm{~s}^{-1}<V_{\mathrm{s} 30}<1500 \mathrm{~m} \mathrm{~s}^{-1}$; (3) the soil profile $\mathrm{C}$ has $360 \mathrm{~m} \mathrm{~s}^{-1}<V_{\mathrm{s} 30}<760 \mathrm{~m} \mathrm{~s}^{-1}$; (4) in the soil profile $\mathrm{D}$, the speed of the shear wave $V_{\mathrm{s} 30}$ is between 180 and $360 \mathrm{~m} \mathrm{~s}^{-1}$; (5) in soil profile $\mathrm{E}$, the speed is less than $180 \mathrm{~m} \mathrm{~s}^{-1}$ and (6) the soil profile $\mathrm{F}$ is a very low resistance soil which requires the presence of a specialist in soils or geotechnical engineer to make an assessment.

To get a better idea of Quito soil types, a seismic refraction study was done in the Metropolitan Park, in a place where there is a rocky outcrop about $30 \mathrm{~m}$ high; see Fig. 5. It was found that $V_{\mathrm{s} 30}=466.27 \mathrm{~m} \mathrm{~s}^{-1}$, so it is a soil type C (Castillo, 2014). In Quito there is definitely no soil type $A$, but there are soil types B-D, as shown in Fig. 4.

\section{New spectra}

The new spectra were estimated at equidistant points $(100 \mathrm{~m})$ of a regular mesh and for the three soil types B-D. In turn, this regular mesh was divided into five areas considered in the Metropolitan District of Quito. In each area, and for each type of soil, spectra was obtained at each point of the mesh, using the three ground motion prediction equations indicated above, and finally, an average spectrum was obtained from these spectra.

In the northern area of Quito, an earthquake of magnitude 6.2, related to the fault segment Ilumbisí La Bota, generates the largest spectral accelerations since it is closer to this area. In the first row of Fig. 6, these spectra are indicated for confidence levels of 50 and $84 \%$, and for soils B-D. Fault segments Puengasí, Carcelén-El Inca, Bellavista-Catequilla and Tangahuilla generate smaller amplitude spectra for this area.

In the last four rows of Figs. 7 and 8 the spectra for the north-central, central, south-central, and southern zones of Quito are presented for an earthquake of magnitude 6.4 on the fault segment of Puengasí. The other fault segments generate lower spectral ordinates.

\section{Recurrence periods}

The return period is the time between the occurrence of two events at the same seismic source. Therefore, it is a concept that helps to estimate the expected time of occurrence of an earthquake of a given magnitude.

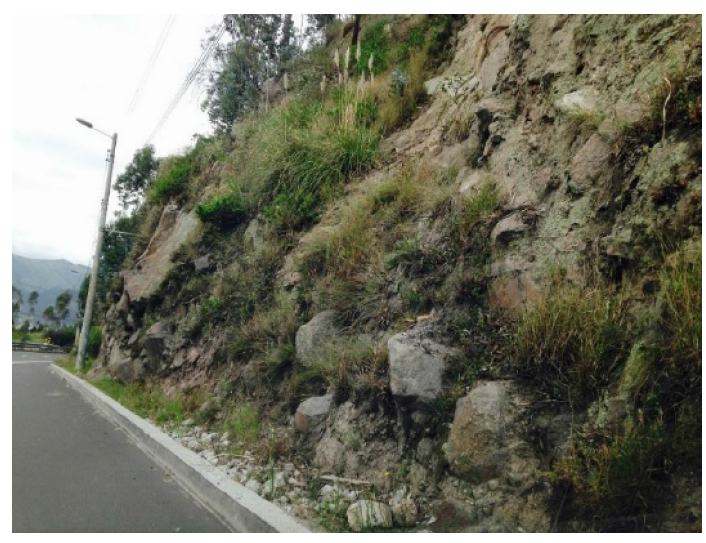

Figure 5. Rocky soil in Quito, $V_{\mathrm{s} 30}=466.27 \mathrm{~m} \mathrm{~s}^{-1}$. Metropolitan Park.

To estimate the recurrence interval associated with different magnitudes within each segment, the seismic potential of the fault should be modeled by the moment rate. This parameter (moment rate) estimates the annual accumulation of energy in each segment of the fault and will be used to relate the slip rate to the assigned recurrence model.

\subsection{Estimation of the seismic moment rate $\left(\dot{M}_{0}\right)$ in each fault segment}

From the size of the fault plane of each segment (Table 1), the slip rate of the segment $\left(3.0-4.0 \mathrm{~mm} \mathrm{yr}^{-1}\right.$ by Alvarado et al., 2014), and with the conservative assumption that all the plane fault is accumulating energy evenly, the moment rate $\dot{M}_{0}$ can be related to the above parameters according to expression of Brune (1968), Eq. (3).

$\dot{M}_{0}=\mu \cdot \dot{u} \cdot A$,

where $\mu$ is the shear modulus $\left(10^{3} \mathrm{~N} \mathrm{~m}^{-2}\right)$ is $\dot{u}$ the slip rate and $A$ is the fault plane area (Table 1). A Supplement with variables and units is included.

\subsection{Seismicity rate estimation using the modified recurrence model GR and $\dot{M}_{0}$}

Recurrence models define the seismic potential failure relating the frequency and size of earthquakes occurring in a particular source in a given time. The parameters used to define the potential seismic quakes are the number of earthquakes of a certain magnitude $\dot{n}(m)$ (the inverse of the period of recurrence in a given time unit), or the cumulative rate of earthquakes of a magnitude higher than a given value $\dot{N}(m)$, and the proportion of large vs. small earthquakes $[b$ or $\beta]$.

Depending on the relationship established between these parameters, the literature offers different models, for example, Gutenberg and Richter (1944), Main and Burton (1981), Chinnery and North (1975), Bath (1978) and Anderson (1979). From all these models, the one published 

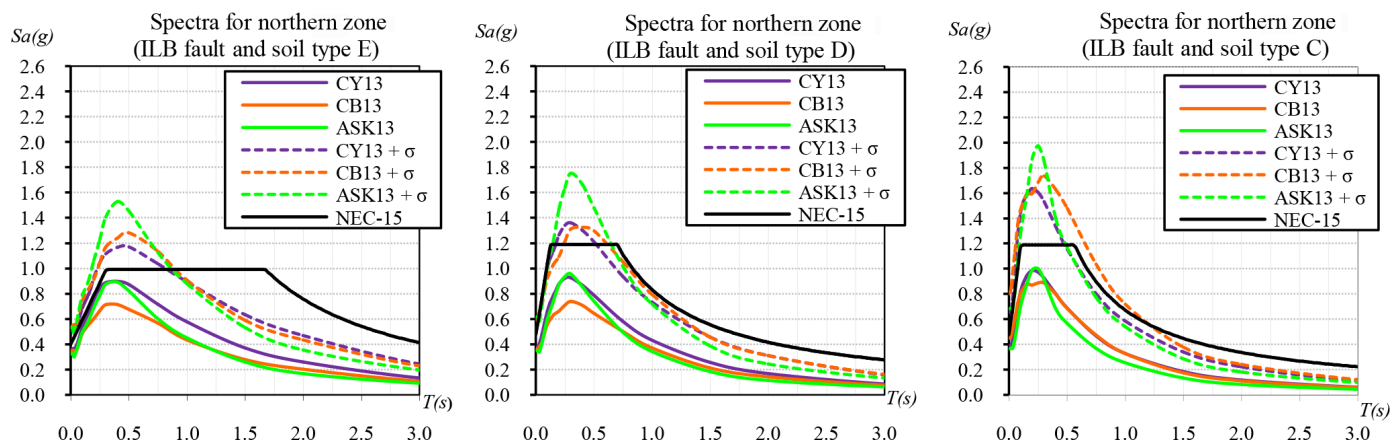

Figure 6. Spectra for the northern zone of Quito.
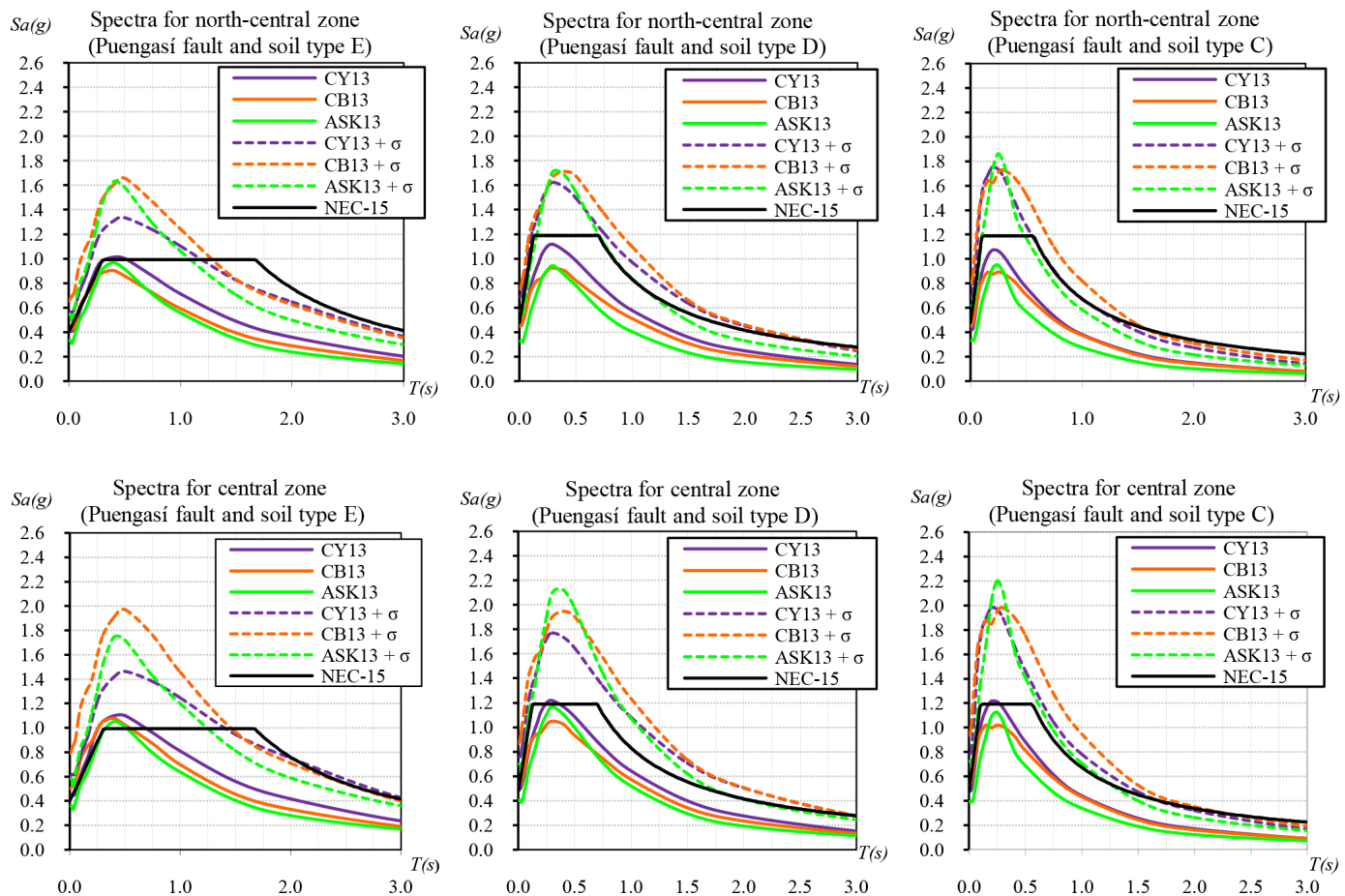

Figure 7. Spectra for north-central and central zones of Quito.

by Gutenberg and Richter (1944) (GR) and modified by Cosentino et al. (1977) is the most widely used for characterizing the source. The Gutenberg-Richter-modified model (Eq. 4) provides a relationship between the cumulative rate of different magnitudes $\dot{N}(m)$, the rate of earthquakes being the number of earthquakes of magnitude less than an established minimum $\left(\dot{N}_{\min }\right)$, generated at a certain time and in a particular area.

$\dot{N}(m)=\dot{N}_{\min } \cdot\left[\frac{\exp (-\beta(m))-\exp \left(-\beta\left(M_{\max }\right)\right)}{\exp \left(-\beta\left(M_{\min }\right)\right)-\exp \left(-\beta\left(M_{\max }\right)\right)}\right]$

From the seismic moment rate, a relationship can be established between this parameter and a recurrence model type GR through the expression of Anderson (1979), Eq. (5).
$\dot{M}_{0}=\int_{M_{\min }}^{M_{\max }} \dot{n}(m) \cdot M_{0}(m) d m$,

where $M_{0}(m)$ is the seismic moment generated in an earthquake of magnitude $m$.

Moreover, Anderson and Luco (1983) propose relationships between the cumulative seismic moment rate $\dot{M}_{0}$ and three models of recurrence: GR-truncated model, GRmodified model and the recurrence model proposed by Main and Burton (1981).

In this paper, the model GR-modified is used, with Eq. (6), where the cumulative rate of earthquakes of magnitude minimum $\dot{N}_{\text {min }}$ is dependent the on moment rate among other parameters, this expression is derived from Eqs. (4) and (5). 
Table 3. Recurrence periods, Gutenberg-Richter-modified model.

\begin{tabular}{lrrrrr}
\hline \multirow{2}{*}{$\begin{array}{l}\text { Magnitude } \\
\text { ranges }\end{array}$} & RUENGASÍ & ILB & CEI & BC & Tangahuilla \\
\cline { 2 - 6 } & PUEurrence periods (years) \\
\hline$[5.0-5.5)$ & $20-35$ & $18-30$ & $27-39$ & $18-31$ & $23-34$ \\
{$[5.5-6.0)$} & $62-87$ & $56-75$ & $85-130$ & $58-78$ & $65-97$ \\
{$[6.0<$} & $164-262$ & $179-279$ & & $169-279$ & $579-1016$ \\
\hline \multirow{2}{*}{$M_{\max }$} & $1224-2190$ & $610-981$ & $549-952$ & $908-1630$ & $579-1016$ \\
& $\left(M_{\mathrm{W}}=6.4\right)$ & $\left(M_{\mathrm{W}}=6.2\right)$ & $\left(M_{\mathrm{W}}=5.9\right)$ & $\left(M_{\mathrm{W}}=6.3\right)$ & $\left(M_{\mathrm{W}}=6.0\right)$ \\
\hline
\end{tabular}
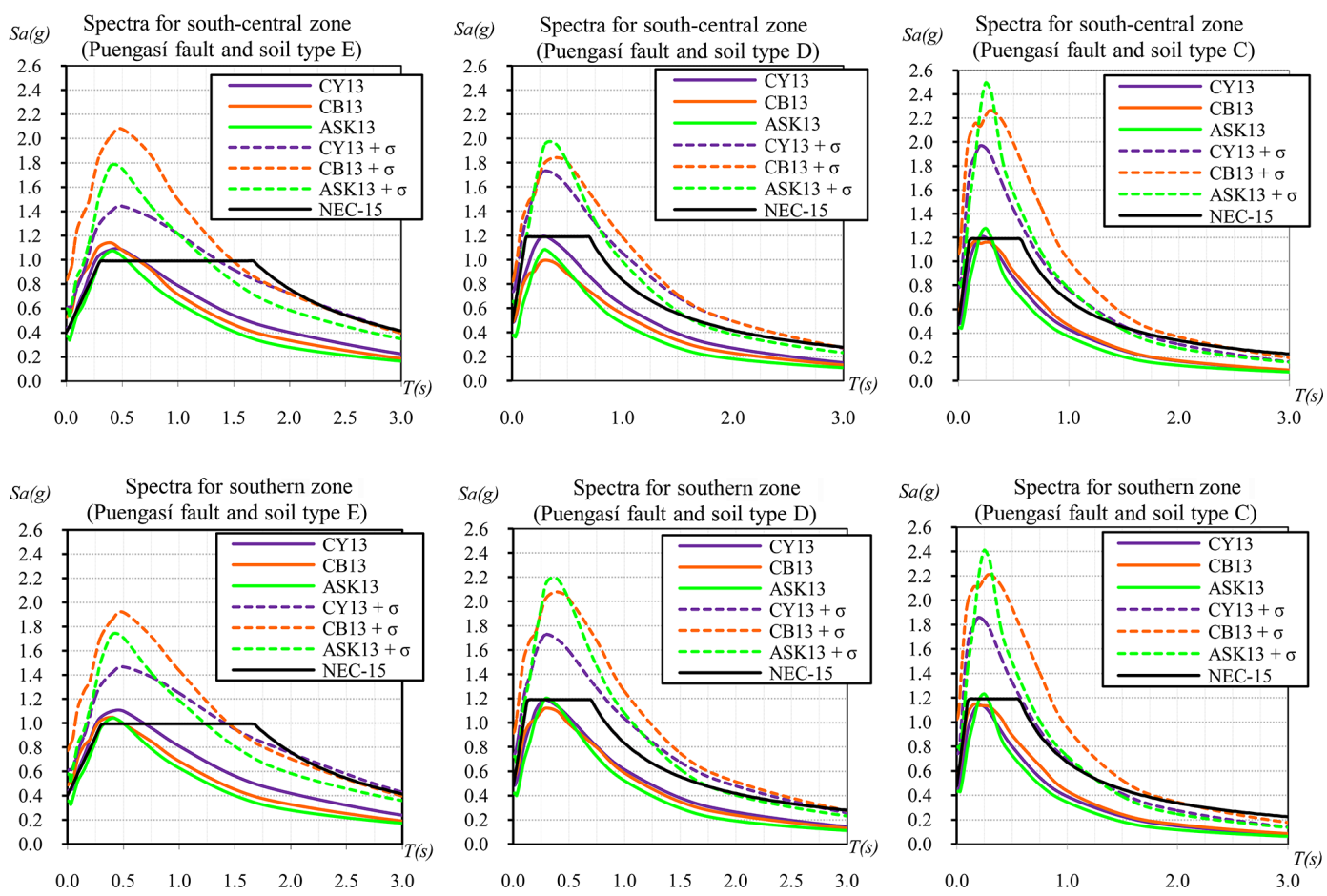

Figure 8. Spectra for south-central and south zones of Quito.

$\dot{N}_{\min }=\frac{\dot{M}_{0}(\bar{d}-\beta)\left(\exp \left(-\beta\left(M_{\min }\right)\right)-\exp \left(-\beta\left(M_{\max }\right)\right)\right)}{\beta\left[\exp \left(-\beta\left(M_{\max }\right)\right) M_{0}\left(M_{\max }\right)-\exp \left(-\beta\left(M_{\min }\right)\right) M_{0}\left(M_{\min }\right)\right]}$,

where $\dot{N}_{\text {min }}$ is the cumulative rate of earthquakes of magnitude greater than or equal to $M_{\min }, \beta$ is a parameter that defines the proportion of earthquakes as a function of their magnitude and will be set to 1.84-2.76 (Rivas-Medina et al., 2014b), $M_{\max }$ and $M_{\min }$ are the maximum and minimum magnitudes of truncation, $M_{0}\left(M_{\max }\right)$ and $M_{0}\left(M_{\min }\right)$ are the seismic moments (co-seismic) that would be released in these possible maximum and minimum magnitude earthquakes, respectively, obtained from the expression of Hanks and Kanamori (1979) and $\bar{d}=1.5 \cdot \ln (10)$.

This expression allows the rate of seismic activity of the fault to be deduced. The calculated values are truncated at a maximum and minimum depending on the rate of seismic moment of the fault.
In Fig. 9, the earthquake cumulative rate is presented for different magnitudes, and for each of the segments of the reverse faults in Quito. From this figure, Table 3 shows the recurrence periods for different magnitude ranges.

As elastic response spectra for maximum magnitudes in each fault segment was obtained, it is interesting to observe the last row of Table 3. For the Puengasí fault, an earthquake of magnitude 6.4 is expected in a time interval between 1224 and 2190 years; for the Ilumbisí-La Bota fault, an earthquake of magnitude 6.2 is expected between 610 and 981 years.

However, it is known that an earthquake of magnitude 6.4 in 1587 in northern Quito, associated with blind faults, caused great damage in the city (Beauval et al., 2010); since then there has not been an earthquake of magnitude greater than 6 associated with these failures, which suggests that there is a significant accumulation of energy in these faults. 


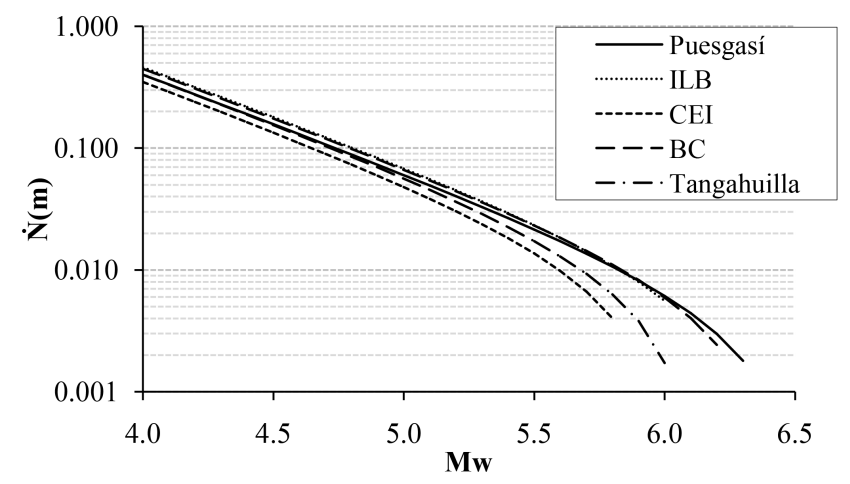

Figure 9. Earthquake cumulative rate for different magnitudes $\dot{N}(m)$ (Rivas-Medina et al., 2014b).

Moreover, the date on which an earthquake with a magnitude greater than 6.0 associated with the Puengasí or Ilumbisí - La Bota faults occurred is not known, so that compliance with the period of recurrence in these failures can be in a few or many years. The truth is that more than four centuries have passed without a strong earthquake and so the likelihood of a severe earthquake in these two fault segments increases.

\section{Commentary and conclusions}

Quito is very close to five active segments of reverse faults called, from south to north, Puengasí, Ilumbisí-La Bota, Carcelen-El Inca, Bellavista-Catequilla and Tanhaguilla.

In this paper, monitoring spectra for the horizontal movement of the soil were computed, for the five areas of the city, south, south-central, central, north and north central, according to the classification of soils of the NEC-15.
These spectra were obtained using the models of Abrahamson et al. (2013), Campbell and Bozorgnia (2013) and Chiou and Youngs (2013) and the maximum magnitude that could be generated in each segment of the blind faults was taken into account. Spectra for the 50 and $84 \%$ confidence levels are also found and the latter have spectral ordinates higher than those found with the NEC-15, so it is important that new construction projects are built in Quito, considering the spectra found in this paper.

Moreover, the recurrence periods were estimated for the maximum magnitude expected in each segment, with which the control spectra recurrence were found, and are between 549 and 2190 years.

Finally, we recommend that the structures should be designed for two denominated spectra: design spectra, similar to those stipulated in the NEC-15, and maximum spectra, which were studied in this work with a confidence of $84 \%$.

The random uncertainty of movement is accounted for through the standard deviation associated with each ground motion prediction equation (the spectra results for 50 and $84 \%$ confidence levels) and the epistemological uncertainty is calculated using the three equations used.

The data on the blind fault system in Quito have been obtained in the last 20 years. There are still many uncertainties, not only in this data but in the method and its results. However, there is no time to lose alerting people about the seismic danger in Quito. The structural designer must be aware of this fact by means of spectra that use the latest available information.

\section{Data availability}

The control spectra of Quito can be accessed by this link: https://docs.google.com/spreadsheets/d/. 
Appendix A: Variables and units used to estimate the recurrence periods

Table A1. Variables and units.

\begin{tabular}{lll}
\hline Abbreviation & Variables & Units \\
\hline$M_{0}$ & seismic moment & $\mathrm{Nm}$ [or dina cm] \\
$\dot{M}_{0}$ & moment rate & $\mathrm{N} \mathrm{mm} \mathrm{yr}$ \\
$\dot{u}$ & slip rate & $\mathrm{mm} \mathrm{yr}^{-1}$ \\
$A$ & fault plane area & $\mathrm{m}^{-2}$ \\
$\dot{n}(m)$ & rate of earthquakes of a certain magnitude & seism yr \\
$\dot{N}(m)$ & $\begin{array}{l}\text { cumulative fate of earthquakes of a magnitude } \\
\text { upper than a given value }\end{array}$ & seism yr \\
& $\begin{array}{l}\text { rate of earthquakes being the number of } \\
\text { earthquakes of magnitude less than an established }\end{array}$ & seism yr \\
$\dot{N}_{\text {min }}$ & minimum & \\
& & \\
\hline
\end{tabular}


Competing interests. The authors declare that they have no conflict of interest.

Acknowledgements. We thank the National Secretary of Higher Education, Science, Technology and Innovation (SENESCYT) of Ecuador for supporting this research.

Edited by: B. D. Malamud

Reviewed by: F. Moreu and one anonymous referee

\section{References}

Abrahamson, N. A., Silva, W. J., and Kamai, R.: Update of the AS08 Ground-Motion Prediction Equations Based on the NGAWest2 Data Set, PEER - Pacific Earthquake Engineering Research Center Headquarters, University of California, Berkeley, 2013.

Aguiar, R.: Microzonificación Sísmica de Quito, 1st Edn., IPGH, Ecuador, p. 212, 2003.

Aguiar, R., Rivas, A., Benito, M., Gaspar, J., Trujillo, S., Arciniegas, S., Villalba, P., and Parra, H.: Aceleraciones registradas y calculadas del sismo del 12 de agosto de 2014 en Quito, Revista Ciencia, 16, 139-153, 2014.

Alvarado, A., Audin, L., Nocquet, J. M., Lagreulet, S., Segovia, M., Font, Y., Lamarque, G., Yepes, H., Mothes, P., Rolandone, F., Jarrin, P., and Quidelleur, X.: Active tectonics in Quito, Ecuador, assessed by geomorphological studies, GPS data, and crustal seismicity, Tectonics, 33, 67-83, doi:10.1002/2012tc003224, 2014.

Anderson, J.: Estimating the seismicity from geological structure for seismic-risk studies, B. Seismol. Soc. Am., 69, 135-158, doi:10.1016/0148-9062(79)90309-7, 1979.

Anderson, J. G. and Luco, J. E.: Consequences of slip rate constants on earthquake occurrence relations, B. Seismol. Soc. Am., 73, 471-496, 1983.

Bath, M.: A note on recurrence relations for earthquakes, Tectonophysics, 51, 23-30, doi:10.1016/0040-1951(78)90047-1, 1978.

Beauval, C., Yepes, H., Bakun, W., Egred, J., Alvarado, A., and Singaucho, J.: Locations and magnitudes of historical earthquakes in the Sierra of Ecuador (1587-1996), Geophys. J. Int., 181, 16131633, doi:10.1111/j.1365-246x.2010.04569.x, 2010.

Brune, J. N.: Seismic moment, seismicity, and rate of slip along major fault zones, J. Geophys. Res., 73, 777-784, doi:10.1029/jb073i002p00777, 1968.

Campbell, K. W. and Bozorgnia, Y.: NGA-West2 CampbellBozorgnia Ground Motion Model for the Horizontal Components of PGA, PGV, and 5\%-Damped Elastic PseudoAcceleration Response Spectra for Periods Ranging from 0.01 to 10 s, PEER - Pacific Earthquake Engineering Research Center Headquarters, University of California, Berkeley, 2013.

Castillo, D.: Espectros de diseño para Quito considerando factores de cercanía asociados a fallas ciegas, Tesis de grado, Universidad de Fuerzas Armadas, ESPE, Quito, Ecuador, p. 160, 2014.

CEC - de la Construcción: Capítulo 1: Peligro sísmico, espectros de diseño y requisitos de cálculo para diseño sismo resistente, XIII Jornadas Nacionales de Ingeniería Estructural, Universidad Católica, Quito, 325-350, 2000.
Chinnery, M. A. and North, R. G.: The frequency of very large earthquakes, Science, 190, 1197-1198, doi:10.1126/science.190.4220.1197, 1975.

Chiou, B. S. J. and Youngs, R. R.: Update of the Chiou and Youngs NGA Ground Motion Model for Average Horizontal Component of Peak Ground Motion and Response Spectra, PEER - Pacific Earthquake Engineering Research Center Headquarters, University of California, Berkeley, 2013.

Cosentino, P., Ficarra, V., and Luzio, D.: Truncated Exponential Frequency Magnitude Relationship in Earthquake Statistics, B. Seismol. Soc. Am., 67, 1615-1623, 1977.

Crouse, C. B. and McGuire, J. W.: Site response studies for purpose of revising NEHRP seismic provisions, Earthq. Spectra, 12, 407439, doi:10.1193/1.1585891, 1996.

De la Construcción, N. E.: Peligro Sísmico/Diseño Sismo Resistente, Código: NEC-SE-DS, Quito, Ecuador, 2015.

Elwood, K: Performance of concrete buildings in the 22 February 2011 Christchurch earthquake and implications for Canadian codes, Can. J. Civ. Eng., 40, 759-776, doi:10.1139/cjce-20110564, 2013.

Field, E. H. and SCEC Phase III Working Group: Accounting for site effects in probabilistic seismic hazard analyses of Southern California: overview of the SCEC Phase III report, B. Seismol. Soc. Am., 90, S1-S31, doi:10.1785/0120000512, 2000.

Gaspar-Escribano, J. M., Benito, B., and García-Mayordomo, J.: Hazard-consistent response spectra in the Region of Murcia (Southeast Spain): comparison to earthquake-resistant provisions, Bull. Earthq. Eng., 6, 179-196, doi:10.1007/s10518-0079051-4, 2008.

Gutenberg, B. and Richter, C. F.: Frequency of earthquakes in California, B. Seismol. Soc. Am., 34, 185-188, doi:10.1038/156371a0, 1944.

Hanks, T. C. and Kanamori, H.: A moment magnitude scale, J. Geophys. Res., 84, 23480-23500, 1979.

Hao, H. and Gaull, B. A.: Estimation of strong seismic ground motion for engineering use in Perth Western Australia, Soil Dynam. Earthq. Eng., 29, 909-924, doi:10.1016/j.soildyn.2008.10.006, 2009.

Leonard, M.: Earthquake fault scaling: Self consistent relating of rupture length width, average displacement, and moment release, B. Seismol. Soc. Am., 100, 1971-1988, doi:10.1785/0120090189, 2010.

Main, I. G. and Burton, P. W.: Rates of crustal deformation inferred from seismic moment and Gumbel's third distribution of extreme magnitude values, Proc. Earthq. Eng., 2, 937-951, 1981.

Nunziata, C., Sacco, C. and Panza, G. F.: Modeling of Ground Motion at Napoli for the 1688 Scenario Earthquake, Pure Appl. Geophys., 168, 495-508, doi:10.1007/s00024-010-0113-1, 2011.

Rivas-Medina, A., Santoyo, M. A., Luzón, F. Benito, B., Gaspar-Escribano, J. M., and García-Jerez, A.: Seismic Hazard and Ground Motion Characterization at the Itoiz Dam (Northern Spain), Pure Appl. Geophys., 169, 1519-1537, doi:10.1007/s00024-011-0405-0, 2011.

Rivas-Medina, A., Martínez-Cuevas, S., Quirós, L. E. GasparEscribano, J. M., and Staller, A.: Models for reproducing the damage scenario of the Lorca earthquake, Bull. Earthq. Eng, 12, 2075-2093, doi:10.1007/s10518-014-9593-1, 2014a.

Rivas-Medina, A., Aguiar, R., Benito, M. B., Gaspar, J. and Parra, H.: Determinación del período de recurrencia y magnitud máx- 
ima para el control de las estructuras en el rango elástico ante un sismo asociado a las fallas inversas de Quito, Revista Internacional de Ingeniería de Estructuras, 19, 201-217, 2014b.

Spudich, P.: The Spudich and Chiou NGA-West2 directivity model, in: chap. 5 in Pacific Earthquake Engineering, PEER - Pacific Earthquake Engineering Research Center Headquarters, University of California, Berkeley, 2013.

Spudich, P. and Chiou, B. S.: Directivity in NGA earthquake ground motions: analysis using isochrone theory, Earthq. Spectra, 24, 279-298, doi:10.1193/1.2928225, 2008.

Trenkamp, R., Kellogg, J. N., Freymueller, J. T., and Mora, H. P.: Wide plate margin deformation, southern Central America and northwestern South America, CASA GPS observations, J. S. Am. Earth Sci., 15, 157-171, doi:10.1016/s0895-9811(02)00018-4, 2002.
Valverde, J., Fernández, J., Jiménez, E., Vaca, T., and Alarcón, F.: Microzonificación sísmica de los suelos del Distrito Metropolitano de la Ciudad de Quito, Escuela Politécnica Nacional del Ecuador, Quito, 2002.

Winter, T., Avouac, J. P., and Lavenu, A.: Late Quaternary kinematics of the Pallatanga strike-slip fault (Central Ecuador) from topographic measurements of displaced morphological features, Geophys. J. Int., 115, 905-920, doi:10.1111/j.1365246x.1993.tb01500.x, 1993. 